\title{
Urantide prevents CCI4-induced acute liver injury in rats by regulating the MAPK signalling pathway
}

\author{
YING LI $^{1}$, ZHEMING GUO $^{2}$, HAIPENG CUI ${ }^{1}$, TU WANG ${ }^{1}$, YUHANG XU ${ }^{1}$ and JUAN ZHAO ${ }^{1}$ \\ ${ }^{1}$ Department of Pathophysiology, Chengde Medical University, Chengde, Hebei 067000; \\ ${ }^{2}$ Second Department of Trauma, Third Hospital of Shijiazhuang City, Shijiazhuang, Hebei 050000, P.R. China
}

Received April 28, 2021; Accepted July 5, 2021

DOI: $10.3892 / \mathrm{mmr} .2021 .12329$

\begin{abstract}
A number of drugs and other triggers can cause acute liver injury (ALI) in clinical practice. Therefore, identifying a safe drug for the prevention of liver injury is important. The aim of the present study was to investigate the potential preventive effect and regulatory mechanism of urantide on carbon tetrachloride $\left(\mathrm{CCl}_{4}\right)$-induced ALI by investigating the expression of components of the MAPK signalling pathway and the urotensin II (UII)/urotensin receptor (UT) system. Liver oedema and severe fatty degeneration of the cytoplasm were observed in ALI model rats, and the serum alanine aminotransferase (ALT) and aspartate aminotransferase (AST) levels were found to be significantly increased. Compared with those in the ALI model group, ALT and AST levels and the liver index did not significantly increase in each group given the preventive administration of urantide, and the liver tissue morphology was correspondingly protected. Moreover, the gene and protein expression levels of UII, G protein-coupled receptor (GPR14) and the oxidative stress-sensitive cytokines, $\alpha$-smooth muscle actin and osteopontin were decreased, indicating that the protein translation process was effectively maintained. However, the expression levels of MAPK signalling pathway-related proteins and genes were decreased. It was found that urantide could effectively block the MAPK signalling pathway by antagonizing the UII/UT system, thus protecting the livers of ALI model rats. Therefore, it was suggested that ALI may be associated with the MAPK signalling pathway, and effective inhibition of the MAPK signalling pathway may be critical in protecting the liver.
\end{abstract}

\section{Introduction}

The liver is an important detoxification organ in the human body that can be damaged by hepatitis virus infection,

Correspondence to: Dr Juan Zhao, Department of Pathophysiology, Chengde Medical University, Anyuan Road, Chengde, Hebei 067000, P.R. China

E-mail: zhaojuan@cdmc.edu.cn

Key words: acute liver injury, urotensin II/urotensin receptor system, urantide, MAPK signalling pathway various drugs $(1,2)$, dietary supplements (3) and hepatotoxic poisons (4). Without effective intervention, this damage may induce acute liver injury (ALI), which has high morbidity and mortality rates $(5,6)$. Carbon tetrachloride $\left(\mathrm{CCl}_{4}\right)$ is a common chemical reagent that is used to establish animal models of acute or chronic liver injury $(7,8)$.

The urotensin II (UII)/urotensin receptor (UT) system is composed of UII and its specific receptor G protein-coupled receptor (GPR14) or UT, and is present in the liver (9), heart (10), kidney (11) and other organs. The UII/UT system has a variety of biological effects, such as inducing contraction, expanding blood vessels and influencing metabolism (12). Furthermore, when liver disease occurs, the UII/UT system is activated (13). Therefore, UII may be a specific target for the treatment of liver injury.

The MAPK pathway is an important cytokine-associated signalling pathway that regulates a variety of biological effects, such as oxidative stress, the inflammatory response, apoptosis, proliferation and differentiation $(14,15)$. The MAPK signalling pathway is abnormally activated in ALI $(16,17)$. Therefore, inhibiting its activation serves a vital role in the prevention and treatment of ALI.

Urantide is the most effective UII receptor antagonist as it has fewer side effects and is 50-100 times more potent than other compounds $(10,18)$. Previous studies have shown that urantide could antagonize the expression of UII/UT system components, thereby effectively alleviating ALI and inhibiting the proliferation of Kupffer cells $(9,19)$. However, to the best of our knowledge, there has been no relevant report on whether the antagonistic UII/UT system affects the MAPK signalling pathway in preventing liver injury.

Therefore, the purpose of the present study was to investigate whether urantide could prevent ALI caused by $\mathrm{CCl}_{4}$ and to identify its regulatory mechanism. We hypothesized that urantide prevented ALI by blocking the UII/UT system and regulating the MAPK signalling pathway.

\section{Materials and methods}

Animals. In total, 50 specific pathogen free healthy male Sprague Dawley rats (weight, 180-200 g; age, 3 weeks) were purchased from Beijing Huafukang Biotechnology Co., Ltd. [licence no. SCXK (Jing) 2019-0008], and one cage for every five rats met the national standard for the minimum area of 
cages occupied by experimental animals. The temperature was set as $22 \pm 2^{\circ} \mathrm{C}$, the humidity was $40-60 \%$ and the light/dark cycle was $12 \mathrm{~h}$ to meet the basic needs of laboratory animals. Animals were provided with free access to food and water. During the experiment, the rats were nursed and treated according to the international guidelines for the use and care of laboratory animals (20).

ALI rat model establishment and preventive administration of urantide. The rats were randomly divided into six groups: Control group, ALI model group, magnesium isoglycyrrhizinate (MgIG) group, urantide low concentration group, urantide medium concentration group and urantide high concentration group, with 10 rats in the ALI model group and 8 rats in each other group. After 1 week of being fed with the basic diet, the mice were fasted for $24 \mathrm{~h}$. The control group and ALI model group were injected with normal saline $(20 \mathrm{mg} / \mathrm{kg})$ through the caudal vein every day for 1 week, the $\mathrm{MgIG}$ group was injected with MgIG (20 mg/kg; Zhengda Tianqing Pharmaceutical Group Co., Ltd.) through the caudal vein every day for 1 week and the treatment group was given 5, 10 and $20 \mathrm{mg} / \mathrm{kg}$ urantide (Suzhou Qiangyao Biological Technology Co., Ltd.) every day for 1 week. After fasting for $2 \mathrm{~h}$, except for those in the control group, the rats were intraperitoneally injected $50 \% \mathrm{CCl}_{4}$ in olive oil $(1 \mathrm{ml} / \mathrm{kg})(21)$, and control group rats were injected with the same amount of olive oil. Each rat was weighed daily.

Blood collection and specimen treatment. After intraperitoneal injection of $\mathrm{CCl}_{4}$ mixed solution for $24 \mathrm{~h}$, an intraperitoneal injection of $150 \mathrm{mg} / \mathrm{kg}$ sodium pentobarbital (Tianjin Fuchen Chemical Industry) was used to euthanise the rats and obtain liver samples. A disposable negative pressure blood collection container (Cangzhou Yongkang Medical Supplies Co., Ltd.) was used to collect blood directly from the abdominal aorta. The blood was centrifuged at $1,500 \mathrm{x}$ g for $10 \mathrm{~min}$ at $4^{\circ} \mathrm{C}$ to obtain plasma. The liver was stored in $4^{\circ} \mathrm{C}$ in $4 \%$ formaldehyde or at $-196^{\circ} \mathrm{C}$ in liquid nitrogen.

Evaluation of liver injury. The body weight of each rat was analysed before administration, before modelling and after the experiment. The serological indexes alanine aminotransferase (ALT) and aspartate aminotransferase (AST) were analysed using the Roche Diagnostics (Shanghai) Co., Ltd. Liver lesions were observed via H\&E staining (Nanchang Yulu Experimental Equipment Co., Ltd.). After fixation using $4 \%$ formaldehyde at $4^{\circ} \mathrm{C}$ for $24 \mathrm{~h}, 5-\mu \mathrm{m}$ thick sections were stained at room temperature with hematoxylin for $5 \mathrm{~min}$ and eosin for $3 \mathrm{~min}$. Stained sections were visualized using a light microscope (magnification, x200 or 1,000). For oil red O staining, cut frozen sections of liver tissue (8- $\mu \mathrm{m}$ thick) were fixed with $10 \%$ formaldehyde at room temperature for $15 \mathrm{~min}$, then stained with oil red $\mathrm{O}$ working solution (Beijing Solarbio Technology Co., Ltd.) for $15 \mathrm{~min}$. Stained sections were visualized using a light microscope (magnification, x200 or 1,000). According to the changes in liver tissue structure, the changes in liver cell morphology, the degree of necrosis and the degree of inflammatory cell infiltration, liver injury was comprehensively judged and semi-quantitative scored as the Liver Injury Score (22). The higher the score, the more severe the liver tissue damage. The specific criteria were as follows: 0 points, liver tissue structure and cell morphology are normal, no obvious degeneration or necrosis, no cell swelling and inflammatory cell infiltration; 1 point, liver cells show limited degeneration or necrosis, and cell swelling can be found, occasionally visible inflammatory cell infiltration and occasionally observed necrosis; 2 points, diffuse degeneration and swelling of liver cells, localized infiltration of inflammatory cells can be found, multiple necrotic areas, occasional focal necrosis; 3 points, liver cells showed watery degeneration and obvious swelling, a large number of inflammatory cells infiltrated, multiple focal necrosis, liver tissue structure disorder; and 4 points, multiple flaky necrosis, liver cord arrangement disorder, liver lobules lose normal structure.

Immunohistochemistry and immunofluorescence analysis. After fixation with $4 \%$ formaldehyde at $4^{\circ} \mathrm{C}$ for $24 \mathrm{~h}$, liver paraffin embedded sections (thickness, $5 \mu \mathrm{m}$ ) were hydrated with gradient concentrations of alcohol (100\% ethanol I, $100 \%$ ethanol II, 95\% ethanol, $90 \%$ ethanol, $80 \%$ ethanol, $70 \%$ ethanol; 2 min each) for immunohistochemistry and immunofluorescence analysis. Each step was carried out in strict accordance with the manufacturer's instructions.

Immunohistochemistry was performed using a polymer detection kit (cat. no. PV-6000; OriGene Technologies, Inc.). Following blocking with peroxidase blocker at $37^{\circ} \mathrm{C}$ for $45 \mathrm{~min}$, primary antibodies $[\alpha$-smooth muscle actin ( $\alpha$-SMA) and osteopontin (OPN) rabbit monoclonal antibodies; 1:100; cat. nos. A1011 and A1499; ABclonal] were added and incubated overnight at $4^{\circ} \mathrm{C}$. Goat anti-rabbit IgG polymer (cat. no. PV-6000; OriGene Technologies, Inc.) was added and incubated at $37^{\circ} \mathrm{C}$ for $45 \mathrm{~min}$. Then, DAB solution (substrate: concentrate $=1: 20$ ) was added and incubated at $37^{\circ} \mathrm{C}$ for $5 \mathrm{~min}$, following which haematoxylin staining was performed for $5 \mathrm{~min}$. Finally, stained sections were observed using a light microscope (magnification, $\mathrm{x} 400$ ).

Immunofluorescence detection was performed using a polymer detection kit (Shanghai Botai Biotechnology Institute). The nuclei were stained with DAPI. The following primary antibodies, phosphorylated (p)-JNK (mouse; 1:200; cat. no. 9255), p-ERK (rabbit; 1:200; cat. no. 4370) and p-P38 (rabbit; 1:1,600; cat. no. 4511), all from Cell Signalling Technology, Inc., were added and incubated overnight at $4^{\circ} \mathrm{C}$. FITC-labelled goat anti-rabbit $\operatorname{IgG}(1: 1,000$; cat. no. 02-15-06; $\mathrm{KPL}$, Inc.) was added and incubated at $37^{\circ} \mathrm{C}$ for $45 \mathrm{~min}$. A fluorescence microscope equipped with a digital high-resolution camera was used for observation (Olympus Corporation). Quantitative analysis was performed using Image-Pro Plus 6.0 software (Media Cybernetics, Inc.).

Reverse transcription-quantitative PCR (RT-qPCR). TRIzol ${ }^{\circledR}$ reagent (Invitrogen; Thermo Fisher Scientific, Inc.) was used to extract RNA from the liver tissue, and cDNA was reverse transcribed using the FastQuant RT kit (Beijing Tiangen Biotechnology Co., Ltd.) containing gDNase according to the manufacturer's protocol. A SuperReal Premix Plus kit (Tiangen Biotechnology Co., Ltd.) was used to measure the expression of related genes. The following thermocycling conditions were used for qPCR: Initial denaturation at $95^{\circ} \mathrm{C}$ for $15 \mathrm{~min}$; 40 of cycles of denaturation at $95^{\circ} \mathrm{C}$ for $10 \mathrm{sec}$, 
Table I. Primer sequences of rat genes.

\begin{tabular}{ll}
\hline Gene & \multicolumn{1}{c}{ Primer sequence } \\
\hline UII & F: 5'-GGAGGAGCTGGAGAGGACTG-3' \\
& R: 5'-GAGTCTCGGCACTGGGATCT-3' \\
GPR14 & F: 5'-AATGGCTCTAGGGTCCTCCT-3' \\
& R: 5'-AACAGCCTCTGTGATGGACA-3' \\
a-SMA & F: 5'-CAGCCAGTCGCCATCAGGAAC-3' \\
& R: 5'-CCAGCAAAGCCCGCCTTACAG-3' \\
OPN & F: 5'-GACGATGATGACGACGACGATGAC-3' \\
& R: 5'-GTGTGCTGGCAGTGAAGGACTC-3' \\
JNK & F: 5'-TGATCGCCAGATCTCAGAAG-3' \\
& R: 5'-CTGAGGGACACAGGTGACAG-3' \\
ERK & F: 5'-TGCACTAGTGTCCCATCAGG-3' \\
& R: 5'-GTCTGCTCTGCACTTCTTGC-3' \\
P38 & F: 5'-AAGCCATGAGGCAAGAAACT-3' \\
& R: 5'-TGCTGTGATCCTCTTATCCG-3' \\
$\beta$ B-actin & F: 5'-CAGGCATTGCTGACAGGATG-3' \\
& R: 5'-TGCTGATCCACATCTGCTGG-3' \\
\hline
\end{tabular}

UII urotensin II; GPR14, G protein-coupled receptor 14; F, forward; $\mathrm{R}$, reverse.

annealing and elongation at $62^{\circ} \mathrm{C}$ for $30 \mathrm{sec}$; and final extension at $65-95^{\circ} \mathrm{C}$ at increments of $0.5^{\circ} \mathrm{C}$ for $5 \mathrm{sec}$. Relative gene expression was calculated using the $2^{-\Delta \Delta \mathrm{Cq}}$ method $(23,24)$. The primer and probe sequences (Takara Biotechnology Co., Ltd.) are shown in Table I.

Western blotting. RIPA protein lysis buffer and PMSF (Beijing Solarbio Technology Co., Ltd.) were used to extract total protein from liver tissue at a ratio of 100:1. The protein content was quantified using a BCA protein concentration assay kit (Beijing Solarbio Biotechnology Co., Ltd.). In total, $45 \mu \mathrm{g}$ protein was electrophoresed via 10\% SDS-PAGE, transferred to PVDF membrane and blocked with 5\% skimmed milk powder at room temperature for $2 \mathrm{~h}$. Subsequently, the primary antibody was added and incubated at $4^{\circ} \mathrm{C}$ for $12-16 \mathrm{~h}$. The primary antibodies used in the experiment included UII rabbit monoclonal antibody $(1: 1,000$, cat. no. DF7281; Affinity Biosciences), GPR14 mouse monoclonal antibody (1:1,000, cat. no. sc-514460; Santa Cruz Biotechnology, Inc.), JNK/p-JNK rabbit/mouse monoclonal antibodies (1:1,000/1:2,000; cat. nos. 9252 and 9255; Cell Signalling Technology, Inc.), ERK/p-ERK rabbit monoclonal antibodies (1:1,000/1:2,000; cat. nos. 4695 and 4370; Cell Signalling Technology, Inc.), P38/p-P38 rabbit monoclonal antibodies (1:1,000; cat. nos. 8690 and 4511; Cell Signalling Technology, Inc.), GAPDH monoclonal antibody (1:5,000; cat. no. AP0066; BioWorld, Inc.) and $\beta$-actin rabbit monoclonal antibody (1:800; cat. no. AP0060; BioWorld, Inc.). HRP-labelled secondary antibodies (1:5,000; cat. nos. AS014 and 074-1806; ABclonal Biotech Co., Ltd. and Beijing XMJ Scientific Co., Ltd., respectively) were added and incubated for $1 \mathrm{~h}$ at room temperature, and the blots were developed using a highly sensitive ECL kit (Beijing Ximeijie Technology
Table II. Effects of different concentrations of urantide on the serum levels of ALT and AST in rats.

\begin{tabular}{lcc}
\hline Group & ALT $(\mathrm{U} / \mathrm{l})$ & AST (U/l) \\
\hline Control & $28.75 \pm 3.40$ & $123.75 \pm 12.82$ \\
ALI & $107.25 \pm 20.95^{\mathrm{b}}$ & $487.75 \pm 97.62^{\mathrm{b}}$ \\
MgIG & $97.75 \pm 6.08^{\mathrm{b}}$ & $361.25 \pm 16.86^{\mathrm{b}, \mathrm{c}}$ \\
Urantide dose & & \\
Low & $76.50 \pm 13.53^{\mathrm{b}, \mathrm{c}, \mathrm{d}}$ & $423.25 \pm 62.71^{\mathrm{b}}$ \\
Middle & $52.00 \pm 12.73^{\mathrm{a}, \mathrm{c}, \mathrm{e}}$ & $333.25 \pm 61.40^{\mathrm{b}, \mathrm{c}}$ \\
High & $46.75 \pm 9.00^{\mathrm{c}, \mathrm{e}}$ & $173.50 \pm 38.79^{\mathrm{c}, \mathrm{e}}$ \\
\hline
\end{tabular}

${ }^{\mathrm{a}} \mathrm{P}<0.05,{ }^{\mathrm{b}} \mathrm{P}<0.01$ vs. control group; ${ }^{\mathrm{c}} \mathrm{P}<0.01$ vs. ALI model group; ${ }^{\mathrm{d}} \mathrm{P}<0.05,{ }^{\mathrm{e}} \mathrm{P}<0.01$ vs. MgIG group. ALI, acute liver injury; MgIG, magnesium isoglycyrrhizinate; ALT, alanine aminotransferase; AST, aspartate aminotransferase.

Table III. Liver weight and liver index in ALI model rats.

\begin{tabular}{lcc}
\hline Group & Liver weight $(\mathrm{g})$ & Liver index $(\%)$ \\
\hline Control & $8.36 \pm 1.60$ & $3.68 \pm 0.63$ \\
ALI & $10.37 \pm 1.06^{\mathrm{a}}$ & $4.44 \pm 0.43^{\mathrm{a}}$ \\
MgIG & $8.51 \pm 0.85^{\mathrm{c}}$ & $3.93 \pm 0.37^{\mathrm{b}}$ \\
Urantide dose & & \\
Low & $8.50 \pm 0.42^{\mathrm{c}}$ & $4.11 \pm 0.08$ \\
Middle & $8.44 \pm 0.40^{\mathrm{c}}$ & $3.94 \pm 0.20^{\mathrm{b}}$ \\
High & $7.98 \pm 0.51^{\mathrm{c}}$ & $3.86 \pm 0.27^{\mathrm{b}}$ \\
\hline
\end{tabular}

The values are presented as the mean \pm SEM. One-way ANOVA was used for statistical analysis. ${ }^{\mathrm{a}}<0.01$ vs. control group; ${ }^{\mathrm{b}} \mathrm{P}<0.05$ and ${ }^{\mathrm{c}} \mathrm{P}<0.01$ vs. ALI model group.

Co., Ltd.). Image-Pro Plus 6.0 (Media Cybernetics, Inc.) optical density analysis software was used to determine the grey values of the protein bands. GAPDH or $\beta$-actin were used as a reference. The relative expression level is the ratio of the grey value of the target protein and reference protein.

Statistical analysis. The data are presented as the mean \pm SEM, and were analysed using SPSS 25.0 (IBM Corp.). One-way ANOVA and Tukey's test were used for comparisons among groups. The liver damage score was analysed using the Kruskal Wallis test, and then the Dunn test was performed for multiple comparisons. GraphPad Prism (version 7; GraphPad Software, Inc.) software was used to generate the graphs. $\mathrm{P}<0.05$ was considered to indicate a statistically significant difference.

\section{Results}

Changes in liver function in ALI model rats. Serum ALT and AST levels in the ALI model group were significantly higher compared with those in the control group $(\mathrm{P}<0.01$; Table II). After 7 days of pre-treatment with different concentrations of urantide, the serum levels of ALT and AST did not increase 

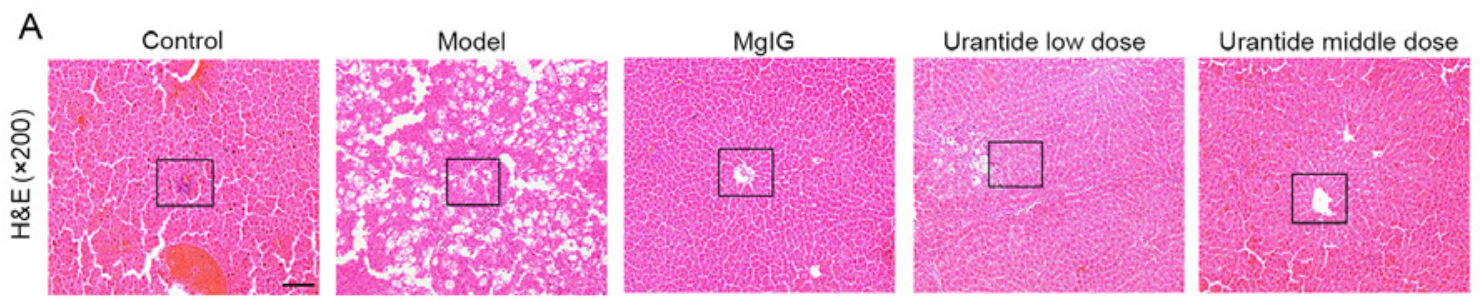

Urantide high dose
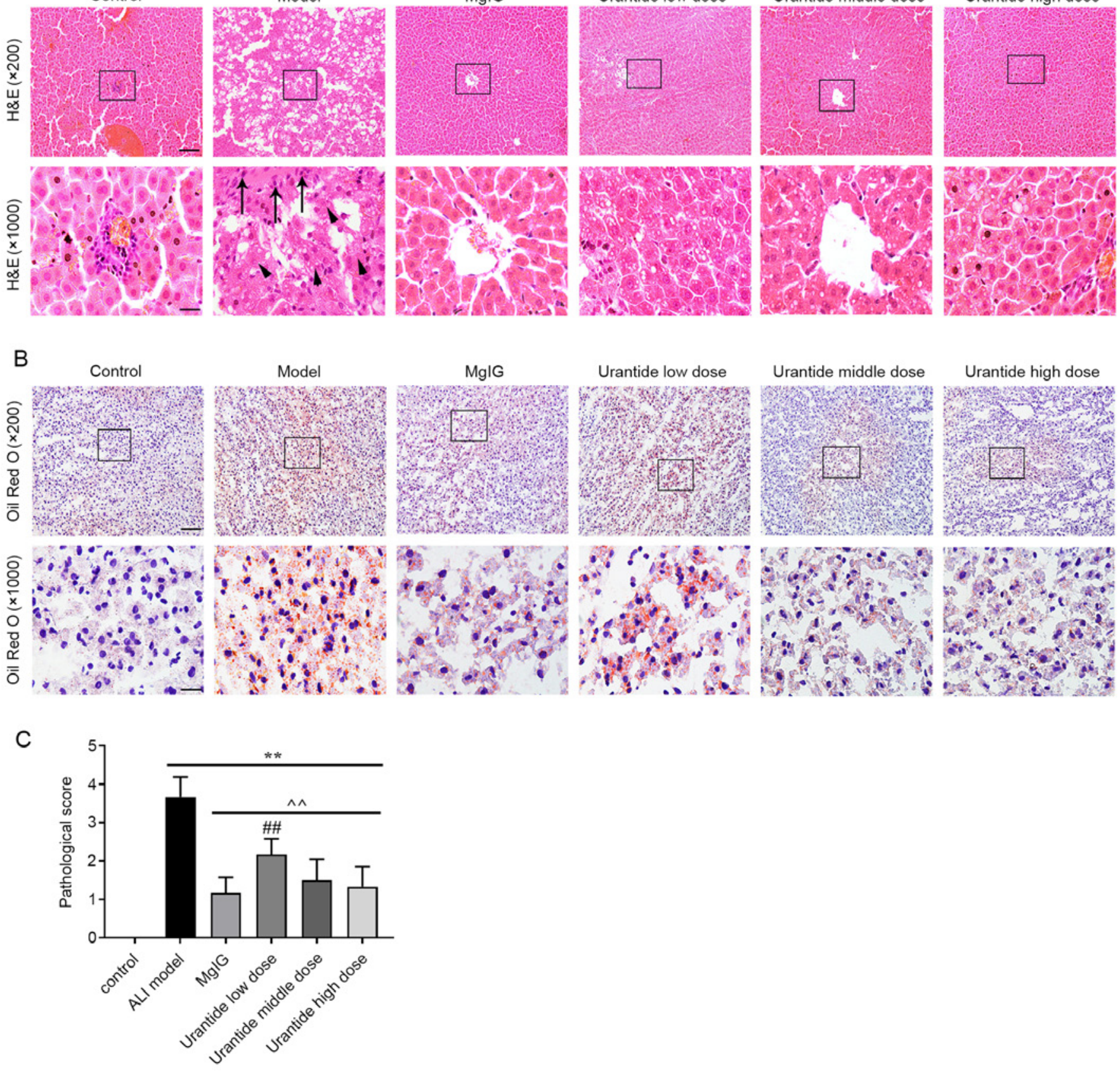

Figure 1. Urantide attenuates liver injury in rats with ALI. (A) Liver tissues were stained with H\&E. Upper panel: Scale bars, $100 \mu \mathrm{m}$. Lower panel: Scale bars, $20 \mu \mathrm{m}$. Triangle, hepatocyte; Arrow, inflammatory cells. (B) Liver tissues were stained with oil red O. Upper panel: Scale bars, $100 \mu \mathrm{m}$. Lower panel: Scale bars, $20 \mu \mathrm{m}$. (C) $\mathrm{H} \& \mathrm{E}$ staining was used to determine the liver injury index score. ${ }^{* *} \mathrm{P}<0.01$ vs. control; ${ }^{\wedge} \mathrm{P}<0.01$ vs. ALI model; ${ }^{\# \#} \mathrm{P}<0.01 \mathrm{vs}$. MgIG. MgIG, magnesium isoglycyrrhizinate; ALI, acute liver injury.

significantly compared with the control group. After urantide pretreatment, ALT in each group was significantly lower compared with that in the ALI group $(\mathrm{P}<0.01)$. After pretreatment with 10 and $20 \mathrm{mg} / \mathrm{kg}$ urantide, AST was significantly lower compared with those in the ALI model group $(\mathrm{P}<0.01)$. After pretreatment with $20 \mathrm{mg} / \mathrm{kg}$ urantide, the preventive effect was significantly higher compared with that in the MgIG group $(\mathrm{P}<0.01)$.

The liver weight and liver index of the ALI model group were significantly higher compared with those of the control group $\left(\mathrm{P}<0.01\right.$; Table III), indicating that $\mathrm{CCl}_{4}$ caused changes in liver weight and liver organ index. When urantide (10 or
$20 \mathrm{mg} / \mathrm{kg}$ ) was administered to the rats, the increase in liver weight and liver index were lower compared with those in the ALI model group $(\mathrm{P}<0.01$ or $\mathrm{P}<0.05)$, and the protective effect was similar to that in the MgIG group.

These results suggested that urantide could protect rats against $\mathrm{CCl}_{4}$-induced liver injury by reducing serum markers, the liver index and liver weight.

Effect of urantide on liver morphology and structure in ALI model rats. In the control group, the liver lobules were normally distributed; the hepatic cords were arranged regularly or distributed in strips, with little fatty degeneration; 
A

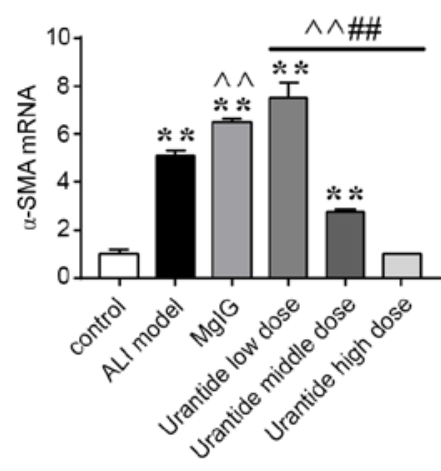

C
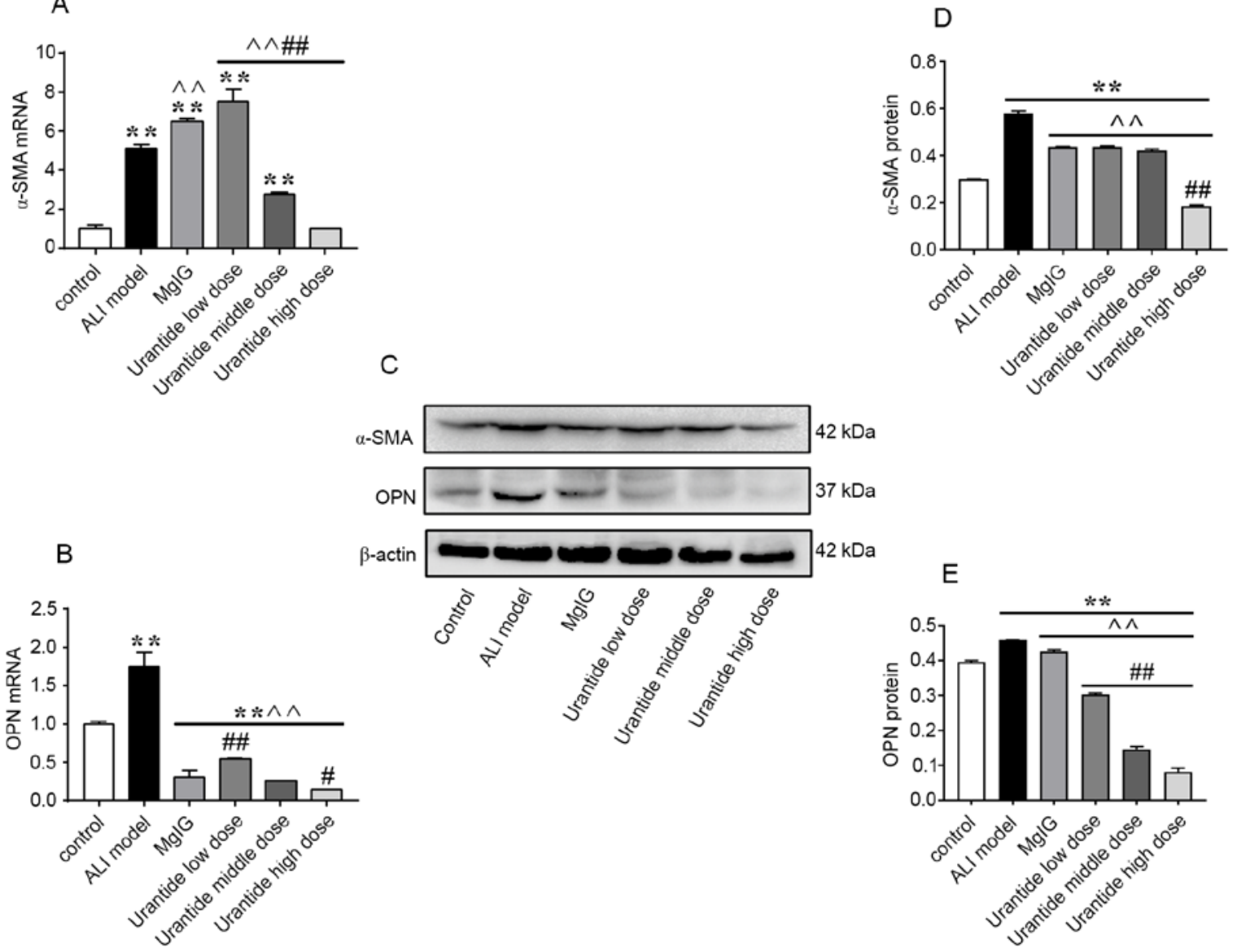

$\beta$-actin
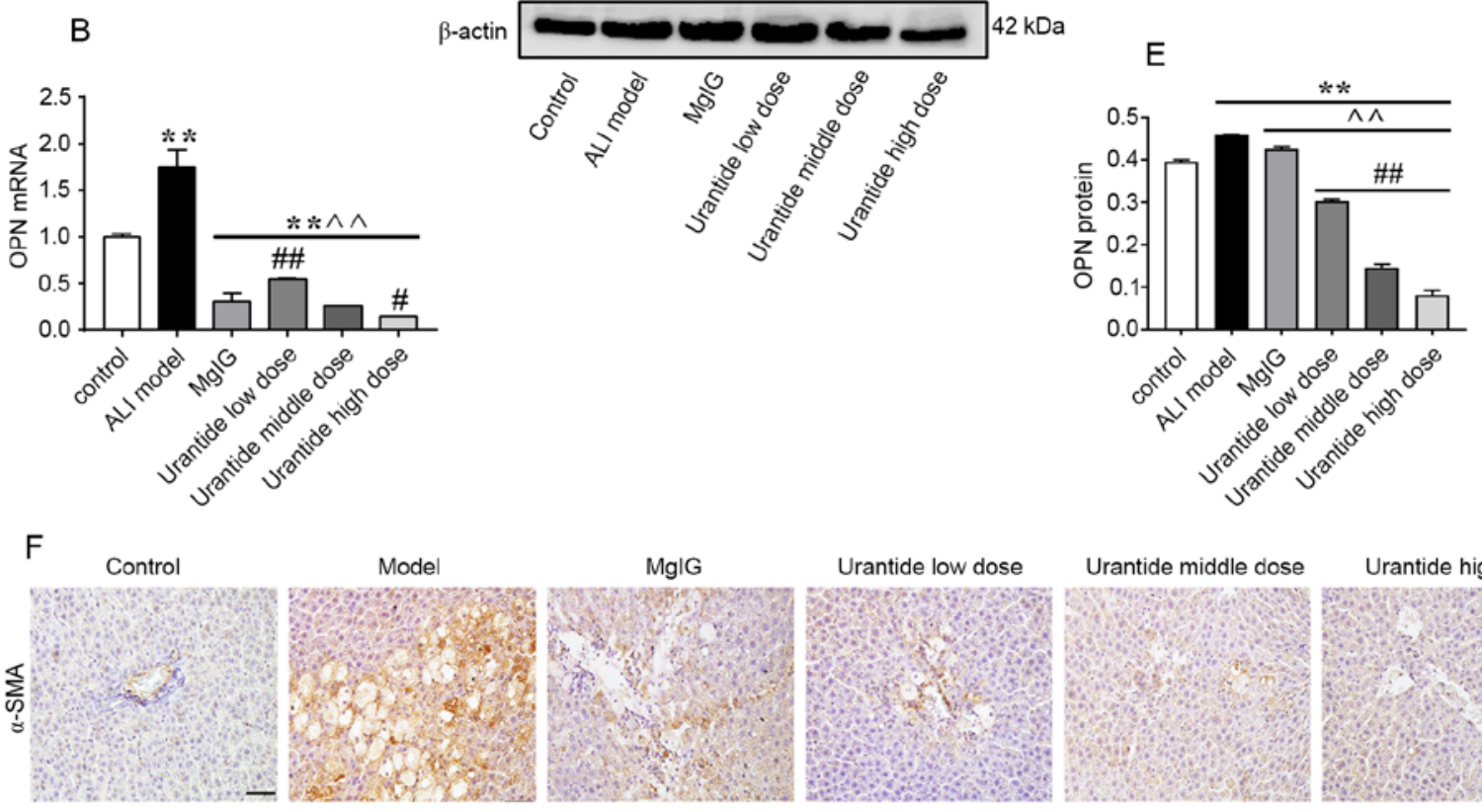

Model

Mg|G

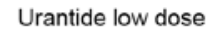

Urantide middle dose

Urantide high dose
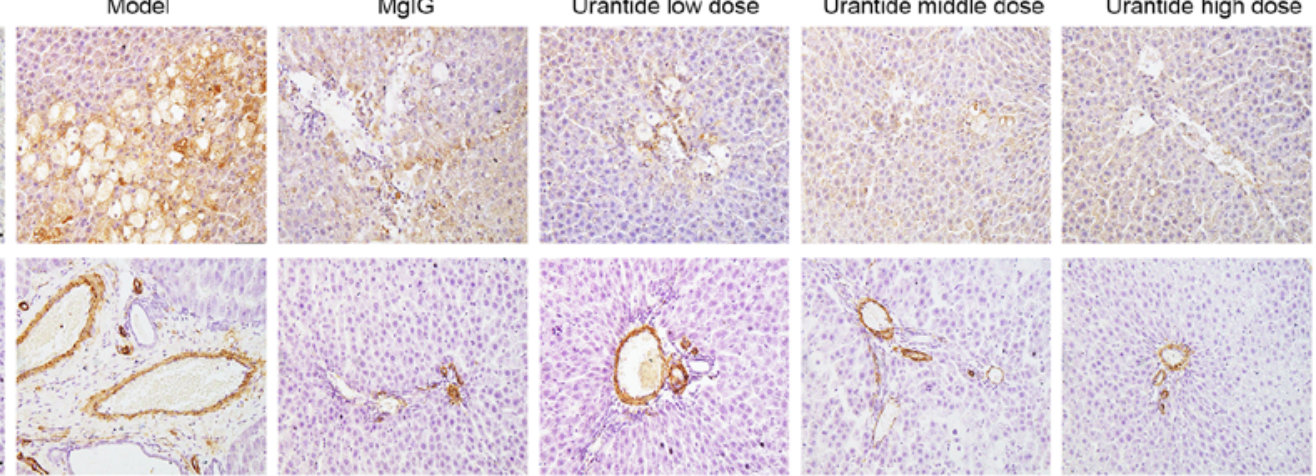

G

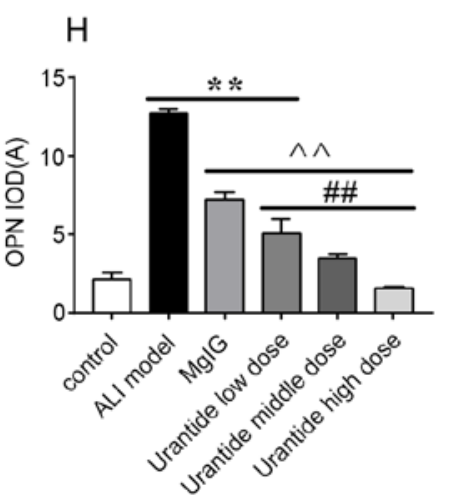

Figure 2. Expression levels of $\alpha$-SMA and OPN in ALI livers were attenuated following urantide administration. The relative (A) gene and (C and D) protein expression levels of $\alpha$-SMA was measured via RT-qPCR and western blotting, respectively. (F) $\alpha$-SMA protein expression was determined via immunohistochemistry. Scale bars, $50 \mu \mathrm{m}$. Corresponding (G) $\alpha$-SMA protein IOD. The relative (B) gene and (C and E) protein expression levels of OPN was measured via RT-qPCR and western blotting, respectively. (F) OPN protein expression was determined via immunohistochemistry (scale bar, $50 \mu \mathrm{m}$ ). Corresponding (H) OPN protein IOD. The data are presented as the mean \pm SEM. For RT-qPCR, western blotting and morphological analysis, $\mathrm{n}=6 \mathrm{per}$ group. ${ }^{* *} \mathrm{P}<0.01$ vs. control; ${ }^{\wedge} \mathrm{P}<0.01$ vs. ALI model; ${ }^{\#} \mathrm{P}<0.05$ and ${ }^{\# \#} \mathrm{P}<0.01$ vs. MgIG. $\alpha$-SMA, $\alpha$-smooth muscle actin; OPN, osteopontin; RT-qPCR, reverse transcription quantitative PCR; IOD, integrated optical density; MgIG, magnesium isoglycyrrhizinate; ALI, ALI, acute liver injury. 
A

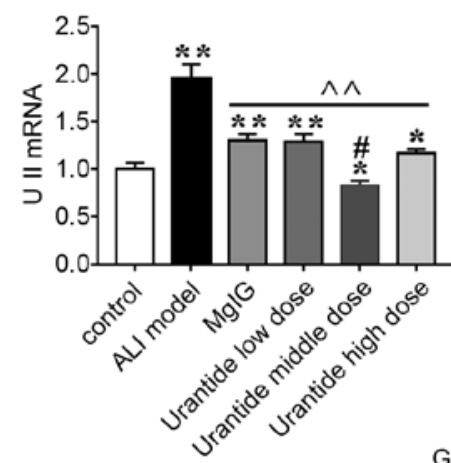

UII

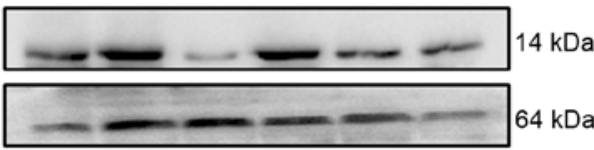

$\beta$-actin

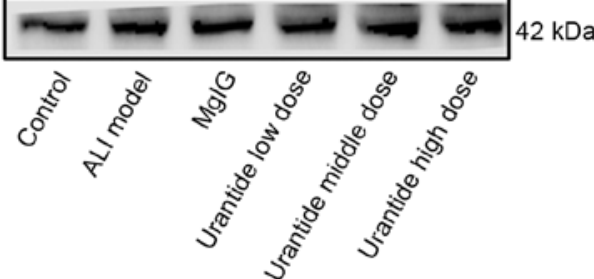

B

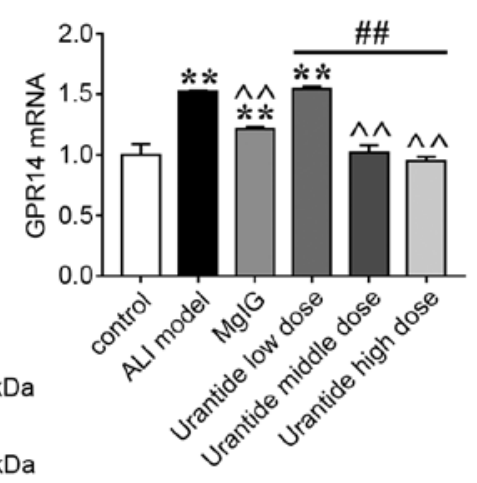

$\mathrm{E}$

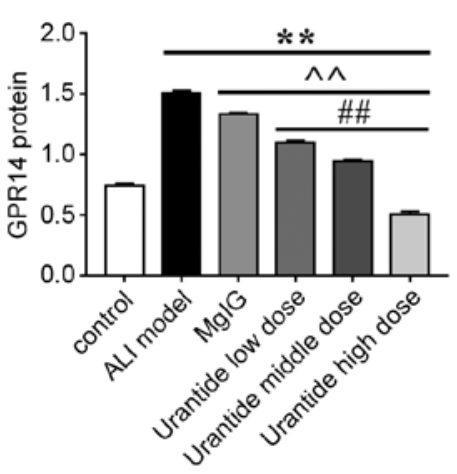

Figure 3. Expression levels of UII and GPR14 in ALI livers was attenuated following urantide administration. Relative (A and B) gene (C) and protein expression levels of UII and GPR14 were measured via RT-qPCR and western blotting, respectively. Relative protein expression of (D) UII and (E) GPR14. The data are presented as the mean \pm SEM. For RT-qPCR, western blotting and morphological analysis, $n=6$ per group. ${ }^{~} \mathrm{P}<0.05$ and ${ }^{* *} \mathrm{P}<0.01$ vs. control; ${ }^{\wedge} \mathrm{P}<0.01 \mathrm{vs}$. ALI model; " $\mathrm{P}<0.05$ and ${ }^{\# \#} \mathrm{P}<0.01$ vs. MgIG. UII, urotensin II; GPR14, receptor G protein-coupled receptor 14; RT-qPCR, reverse transcription PCR; MgIG, magnesium isoglycyrrhizinate; ALI, ALI, acute liver injury.

and there was no blood stasis in the liver sinuses. In the ALI model group, the liver showed a large area of oedema, hepatocyte atrophy occurred, severe steatosis was present in the cytoplasm, there was severe structural damage and necrosis of some hepatocytes, nuclei dissolved and disappeared, and the liver sinus was widened (Fig. 1A and B). Compared with that of the ALI model group, the liver tissue morphology was correspondingly protected in the MgIG group and urantide groups. According to liver histopathology scoring standard, the pathological scores of liver tissues in each group were evaluated. There was almost no pathological change in the control group, while the average pathological score of the ALI model group was 3.67. Compared with those of the ALI model group, the average pathological scores of the urantide low, medium and high concentration groups were 2.17, 1.50 and 1.33, respectively (Fig. 1C). The histological and pathological scores demonstrated that urantide could effectively prevent $\mathrm{CCl}_{4}$-induced ALI and protect the liver tissue of ALI model rats.

Expression levels of $\alpha$-SMA and OPN in the liver. $\alpha$-SMA and OPN are oxidative stress-sensitive cytokines that are associated with the degree of liver injury (25-27). Compared with those in the control group, the mRNA and protein expression levels of $\alpha$-SMA and OPN in the liver tissue of the ALI model group were significantly increased $(\mathrm{P}<0.01$; Fig. 2A-E). ALI also led to a significant increase in the total number of positive granules. $\alpha$-SMA was mainly found in the common bile duct of the liver in ALI model rats, but OPN was mainly found in the cytoplasm of liver cells with degeneration and necrosis, while a small amount was distributed in the stroma (Fig. 2F-H). After preventive administration of urantide, the expression levels of $\alpha$-SMA and OPN, and positive particles were decreased $(\mathrm{P}<0.01)$. Moreover, the preventive effect of urantide was greater than that of MgIG. These results indicated that $\alpha$-SMA and OPN could serve important roles in ALI. Thus, inhibiting $\alpha$-SMA and OPN could effectively prevent ALI.

Expression of UII/UT system components in the liver. Compared with that in the control group, the liver expression of UII/UT in the ALI model group was significantly increased $(\mathrm{P}<0.01$; Fig. 3A-E). After the preventive administration of the UII receptor antagonist urantide, the expression of the GPR14 protein and gene was downregulated in a 

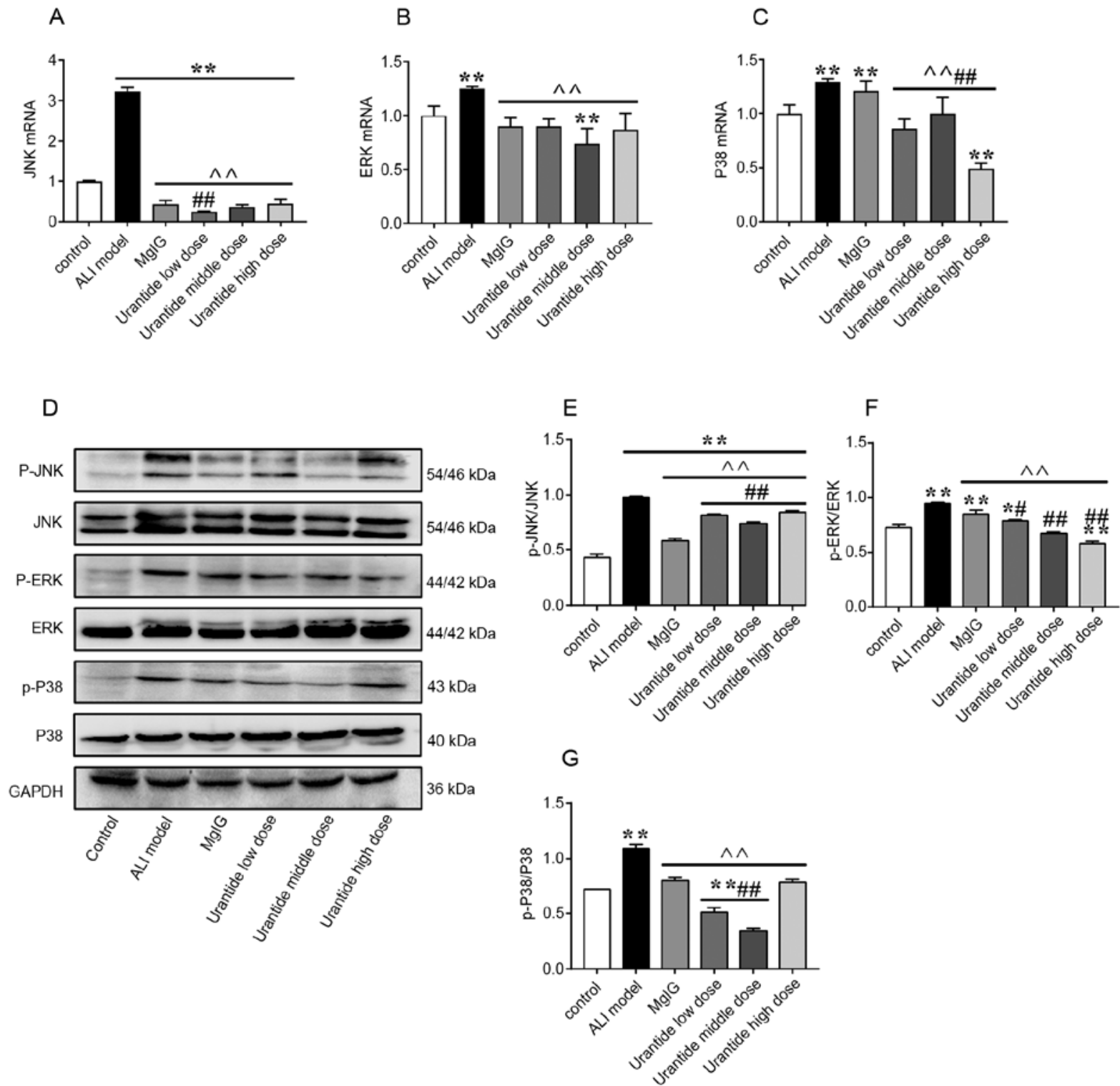

Figure 4. Downregulation of JNK, ERK and P38 in the liver. The gene expression levels of the signalling pathway components (A) JNK, (B) ERK and (C) P38 were measured via RT-qPCR. (D) The protein expression of (E) JNK, (F) ERK and (G) P38 was measured by western blotting. The data are presented as the mean \pm SEM. For RT-qPCR and western blot analysis, $n=6$ per group. ${ }^{*} \mathrm{P}<0.05$ and ${ }^{* * *} \mathrm{P}<0.01$ vs. control; ${ }^{\wedge} \mathrm{P}<0.01$ vs. ALI model; ${ }^{\#} \mathrm{P}<0.05$ and ${ }^{\# \prime \prime} \mathrm{P}<0.01$ vs. MgIG. p-, phosphorylated; RT-qPCR, reverse transcription quantitative PCR; MgIG, magnesium isoglycyrrhizinate; ALI, ALI, acute liver injury.

concentration-dependent manner, and the expression of the UII protein and gene was downregulated compared with the ALI model group, indicating that the activation state of the UII/UT system was effectively regulated, and the stress ability of rats was effectively improved. Furthermore, the therapeutic effect of urantide was greater than that of MgIG. These results indicate that the UII/UT system may play an important role in ALI and that inhibiting the UII/UT system could effectively protect the liver.

MAPK signalling pathway in the liver. To verify how the UII/UT system works, the gene and protein expression of MAPK signalling pathway factors that are associated with liver injury were examined in ALI model rats. ALI induced the gene expression of JNK, ERK and P38 in the rat liver (Fig. 4A-C). Moreover, the protein expression levels of p-JNK/ JNK, p-ERK/ERK and p-P38/P38 were increased after ALI induction (Fig. 4D-G). Next, it was investigated whether the binding of UII to its receptor on the cell membrane has a series of biological effects that regulate the MAPK signalling pathway. Changes in the MAPK signalling pathway were further observed in ALI model rats that were pretreated with urantide for 1 week. Compared with that in the ALI model group, the expression of MAPK signalling pathway-related genes and proteins were significantly reduced in the urantide groups $(\mathrm{P}<0.01)$. These results suggested that urantide could effectively protect the liver function of ALI model rats by regulating the MAPK signalling pathway.

Localization of MAPK signalling pathway proteins. When analysing the localization of $\alpha$-SMA and OPN, it was found that these proteins were mainly expressed in the cytoplasm of hepatocytes of ALI model rats. Immunofluorescence analysis confirmed that p-JNK, p-ERK and p-P38 exhibited similar 

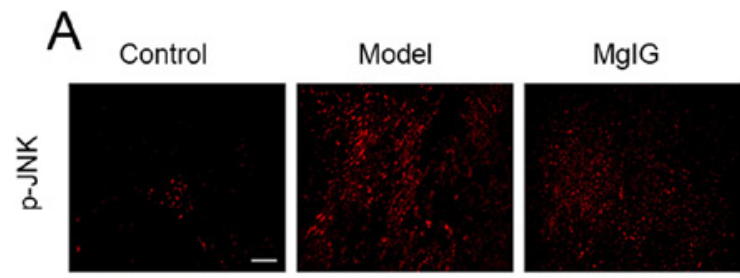

Urantide low dose Urantide middle dose Urantide high dose
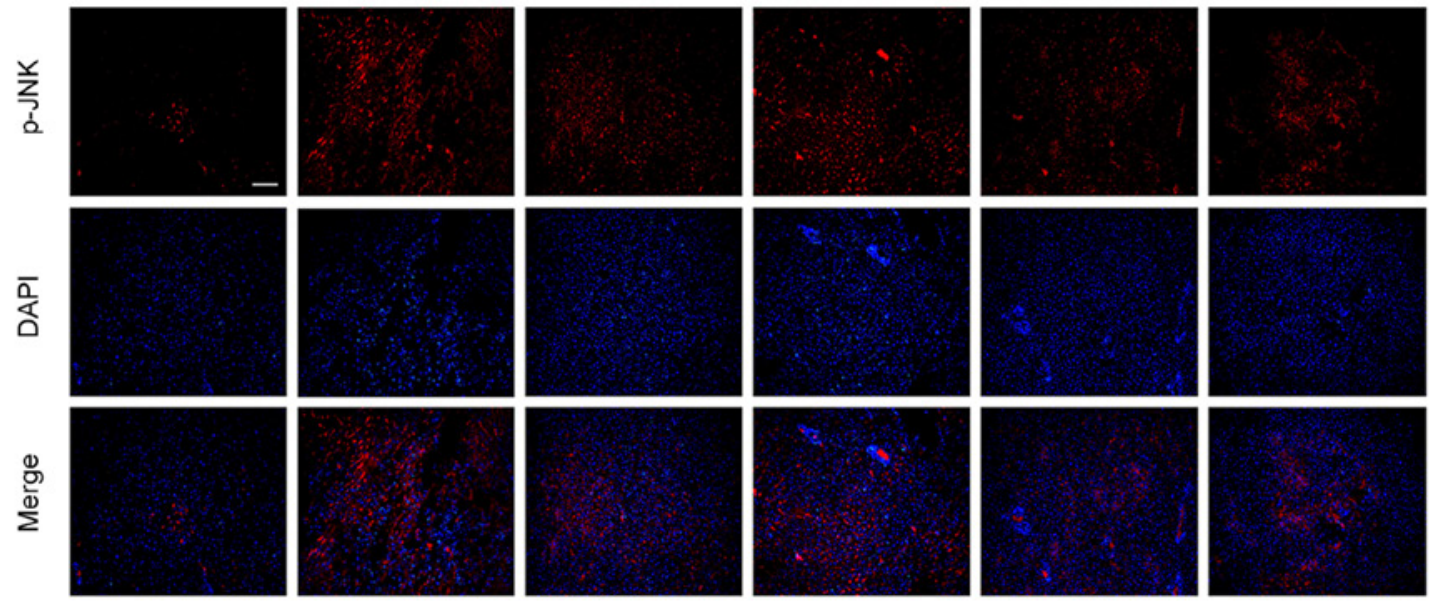

B
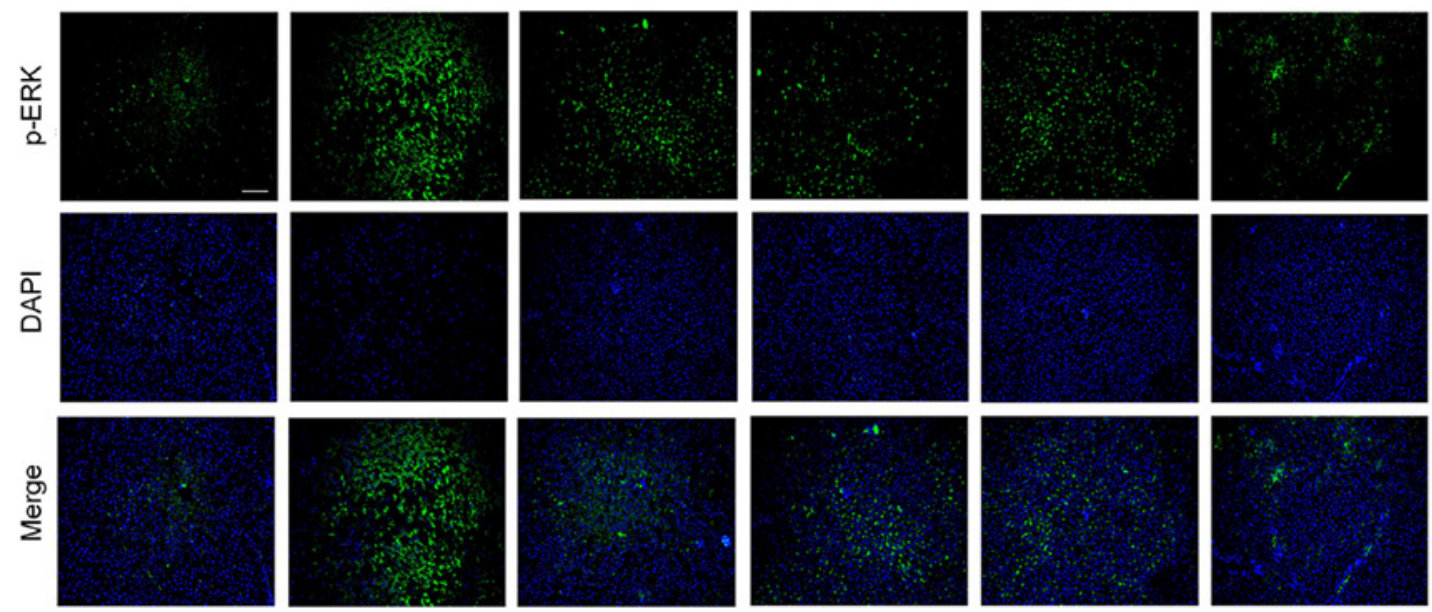

C
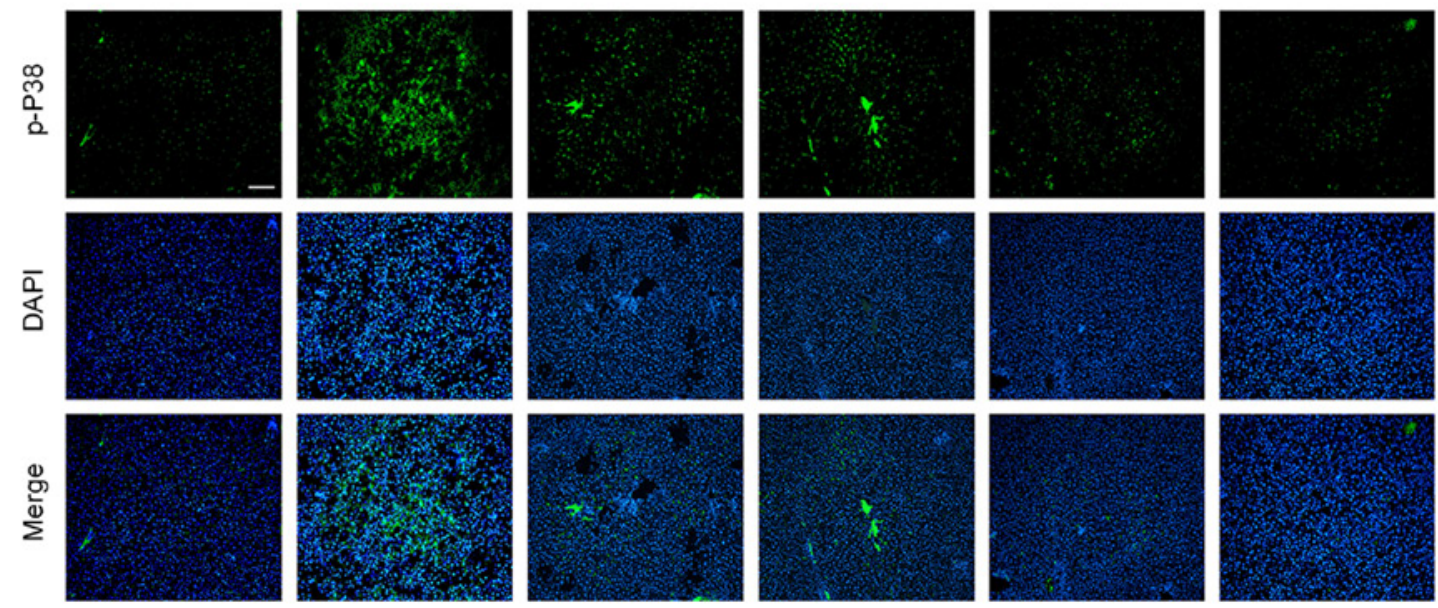

Figure 5. Expression levels of p-JNK, p-ERK and p-P38 in the cytoplasm of hepatocytes were significantly different. Red and green fluorescent signals were downregulated in acute liver injury rat liver tissue following urantide administration. Immunofluorescence was used to determine the expression levels of p-JNK (FITC-labelled, red) (A), p-ERK (B) and p-P38 (FITC-labelled, green) (C). The nuclei were stained with DAPI (blue). Scale bars, $50 \mu \mathrm{m}$. p-, phosphorylated; MgIG, magnesium isoglycyrrhizinate.

expression patterns (Fig. 5A-C). It was concluded that the MAPK signalling pathway was activated during ALI, and that the localized expression of MAPK signalling proteins was similar to that of $\alpha$-SMA and OPN. Moreover, the expression levels of p-JNK, p-ERK and p-P38 in rats gradually became normal after the preventive administration of urantide. 


\section{Discussion}

A 2017 global burden of disease study showed that $\sim 500,000$ individuals die of liver injury every year in China (28). Although there are numerous hepatoprotective drugs used in clinical practice, their side effects are significant; therefore, new targeted drugs are urgently required for clinical use $(2,29)$. For this reason, the current study used more specific and safer peptide compounds for ALI research to provide new options for the clinical prevention and treatment of diseases.

The present study demonstrated that when $\mathrm{CCl}_{4}$ induced ALI, the liver function indexes ALT and AST increased significantly. Moreover, the histomorphology of the liver showed significant pathological changes, and the two trends were consistent with results by Munakarmi et al (30) and other studies $(31,32)$. In addition, the current results indicated that the UII/UT system in the liver was activated, and the oxidative stress-sensitive cytokines $\alpha$-SMA and OPN, which can be used to assess liver injury, also underwent significant changes. Interestingly, the expression of proteins and genes related to the MAPK signalling pathway were also changed with the development of the disease. We hypothesize that antagonizing the UII/UT system and regulating the oxidative stress-induced MAPK signalling pathway through preventive administration may have a protective effect against ALI. However, the role of the UII/UT system in oxidative stress in ALI model rats has rarely been reported, and thus, the current study conducted related research. Studies have shown that, although MgIG could protect the liver in ALI and exert a variety of biological effects, its preventive and therapeutic efficacy is not yet ideal. Therefore, it remains necessary to further evaluate the occurrence and development of ALI.

Urantide is a UII receptor antagonist peptide based on human UII, which is currently the strongest known UII receptor antagonist. Our previous study showed that urantide could effectively inhibit the MAPK signalling pathway in the tissues of atherosclerotic rats (10). Studies have revealed that urantide has antioxidant and anti-inflammatory effects and served a key role in $\mathrm{CCl}_{4}$-induced ALI (33-36). The present results indicated that, after 1 week of preventive urantide administration, the serum levels of ALT and AST did not increase significantly. Consistent with this finding, the pathological changes gradually approached normal states.

Liu et al (9) and other studies reported that preventive administration of urantide could effectively improve the body's ability to resist damage, and in the presence of pathogenic factors, urantide could effectively antagonize the UII/UT system to protect against damage $(19,37)$. At the same time, it was found that MAPK signalling pathway was activated after liver injury $(16,38,39)$. Moreover, the present study conducted related research to determine whether antagonizing the UII/UT system has an impact on the regulation of the oxidative stress-induced MAPK signalling pathway.

The current results indicated that, after prophylactic urantide administration, the activity of the MAPK signalling pathway in liver tissue was effectively inhibited compared with that in the ALI model group. Similarly, the expression levels of the oxidative stress-sensitive cytokines, $\alpha$-SMA and OPN, were also decreased. This finding indicates that effective regulation of oxidative stress may have a significant protective effect against strong pathogenic factors that induce liver damage.

In conclusion, urantide alleviated $\mathrm{CCl}_{4}$-induced ALI. The objective of the present study was to investigate the preventive effect of urantide on $\mathrm{CCl}_{4}$-induced liver injury in rats. It was suggested that after urantide pretreatment, the serological indexes ALT and AST did not increase significantly, and the liver tissue morphology was protected accordingly. At the same time, urantide could reduce the $\mathrm{CCl}_{4}$-induced ALI toxicity by antagonizing the UII/UT system and regulating the activation of the MAPK signalling pathway, as well as improved the stress ability of ALI model rats, thereby serving a role in protecting the liver. Therefore, uratide may become a hepatoprotective drug clinically. However, whether the UII/ UT system directly or indirectly affects the MAPK signalling pathway requires further research and verification. Although it was found that urantide has a preventive and protective effect against $\mathrm{CCl}_{4}$-induced ALI, the exact mechanism remains unclear. In the future, further research will be conducted to explain the specific mechanism and provide detailed experimental data for liver damage caused by various aetiologies. This study only evaluated animals in the early stage after $\mathrm{CCl}_{4}$ administration, and late effects will be examined in future studies.

\section{Acknowledgements}

The authors would like to thank Mr. Long Chen (Chengde Medical University, Basic Research Institute, China) for the support with the technology for oil red O staining.

\section{Funding}

This study received funding from the Hebei Provincial Natural Science Foundation (grant no. H2020406011), Hebei Provincial Party Committee Organization Department Youth Top Talent Project [grant no. JZZ (2016) No. 9], Hebei Provincial Science and Technology Department Science and Technology Innovation Guidance Special Project, Hebei Provincial Department of Education Key Project (grant no. ZD2019098), Hebei Provincial Department of Education Outstanding Youth Fund Project (grant no. YQ2013005), Chengde Medical College National Natural Science Foundation Project Cultivation Fund (grant no. 201916) and Key Subjects (Pathology and Pathophysiology) at Colleges and Universities of Hebei Province.

\section{Availability of data and materials}

The datasets used and/or analysed during the current study are available from the corresponding author upon reasonable request.

\section{Authors' contributions}

$\mathrm{JZ}$ and YL conceived and designed the study. YL, ZG, HC, TW and YX carried out the experiments. TW and YL carried out the animal model experiments. YL analysed the data. JZ, YL and TW confirmed the authenticity of the raw data. YL wrote the manuscript. All authors carefully reviewed the manuscript, and read and approved the final version of the manuscript. 


\section{Ethics approval and consent to participate}

The protocol was approved by the Ethics Committee of Experimental Animal Center of Chengde Medical University (approval no. CDMULAC-201917-017, January 1, 2020). This study adhered to ARRIVE guidelines/methodology.

\section{Patient consent for publication}

Not applicable.

\section{Competing interests}

The authors declare that they have no competing interests.

\section{References}

1. Chen M, Borlak J and Tong W: High lipophilicity and high daily dose of oral medications are associated with significant risk for drug-induced liver injury. Hepatology 58: 388-396, 2013.

2. McGill MR and Jaeschke H: Biomarkers of drug-induced liver injury: Progress and utility in research, medicine, and regulation. Expert Rev Mol Diagn 18: 797-807, 2018.

3. Crescioli G, Lombardi N, Bettiol A, Marconi E, Risaliti F, Bertoni M, Menniti Ippolito F, Maggini V, Gallo E, Firenzuoli F, et al: Acute liver injury following Garcinia cambogia weight-loss supplementation: Case series and literature review. Intern Emerg Med 13: 857-872, 2018.

4. Allard J,Le Guillou D, Begriche K and Fromenty B: Drug-induced liver injury in obesity and nonalcoholic fatty liver disease. Adv Pharmacol 85: 75-107, 2019.

5. Dai C, Xiao X, Li D, Tun S, Wang Y, Velkov T and Tang S: Chloroquine ameliorates carbon tetrachloride-induced acute liver injury in mice via the concomitant inhibition of inflammation and induction of apoptosis. Cell Death Dis 9: 1164, 2018

6. Wendon J, Cordoba J, Dhawan A, Larsen FS, Manns M, Samuel D, Simpson KJ, Yaron I, Bernardi M, European Association for the Study of the Liver. Electronic address: easloffice@easloffice.eu, et al; EASL Governing Board representative: EASL Clinical Practical Guidelines on the management of acute (fulminant) liver failure. J Hepatol 66: 1047-1081, 2017.

7. Ramos-Tovar E, Hernández-Aquino E, Casas-Grajales S, Buendia-Montaño LD, Galindo-Gómez S, Camacho J, Tsutsumi V and Muriel P: Stevia prevents acute and chronic liver injury induced by carbon tetrachloride by blocking oxidative stress through Nrf2 upregulation. Oxid Med Cell Longev 2018: 3823426, 2018.

8. Schueller F, Roy S, Loosen SH, Alder J, Koppe C, Schneider AT, Wandrer F, Bantel H, Vucur M, Mi QS, et al: miR-223 represents a biomarker in acute and chronic liver injury. Clin Sci (Lond) 131: 1971-1987, 2017.

9. Liu LM, Tu WJ, Zhu T, Wang XT, Tan ZL, Zhong H, Gao DY and Liang DY: IRF3 is an important molecule in the UII/UT system and mediates immune inflammatory injury in acute liver failure. Oncotarget 7: 49027-49041, 2016.

10. Zhao J, Miao G, Wang T, Li J and Xie L: Urantide attenuates myocardial damage in atherosclerotic rats by regulating the MAPK signalling pathway. Life Sci 262: 118551, 2020.

11. Wang T, Xie YQ, Miao GX, Cui HP, Liu K, Li Y, Li Y and Zhao J: Urotensin receptor antagonist urantide improves atherosclerosis-related kidney injury by inhibiting JAK2/STAT3 signaling pathway in rats. Life Sci 247: 117421, 2020.

12. Ross B, McKendy K and Giaid A: Role of urotensin II in health and disease. Am J Physiol Regul Integr Comp Physiol 298: R1156-R1172, 2010

13. Leifeld L, Clemens C, Heller J, Trebicka J, Sauerbruch T and Spengler U: Expression of urotensin II and its receptor in human liver cirrhosis and fulminant hepatic failure. Dig Dis Sci 55: 1458-1464, 2010.

14. Haston S, Pozzi S, Carreno G, Manshaei S, Panousopoulos L, Gonzalez-Meljem JM, Apps JR, Virasami A, Thavaraj S, Gutteridge A, et al: MAPK pathway control of stem cell proliferation and differentiation in the embryonic pituitary provides insights into the pathogenesis of papillary craniopharyngioma. Development 144: 2141-2152, 2017.
15. Peng Z, Gong X, Yang Y, Huang L, Zhang Q, Zhang P, Wan R and Zhang B: Hepatoprotective effect of quercetin against LPS/d-GalN induced acute liver injury in mice by inhibiting the IKK/NF- $\kappa \mathrm{B}$ and MAPK signal pathways. Int Immunopharmacol 52: 281-289, 2017.

16. Ko IG, Jin JJ, Hwang L, Kim SH, Kim CJ, Han JH, Lee S, Kim HI, Shin HP and Jeon JW: Polydeoxyribonucleotide exerts protective effect against $\mathrm{CCl}_{4}$-induced acute liver injury through inactivation of NF- $\kappa \mathrm{B} / \mathrm{MAPK}$ signaling pathway in mice. Int $\mathrm{J}$ Mol Sci 21: 7894, 2020

17. Wang H, Wei X, Wei X, Sun X, Huang X, Liang Y, Xu W, Zhu X, Lin $X$ and Lin J: 4-hydroxybenzo[d] oxazol-2(3H)-one ameliorates LPS/D-GalN-induced acute liver injury by inhibiting TLR4/NF- $\mathrm{BB}$ and MAPK signaling pathways in mice. Int Immunopharmacol 83: 106445, 2020.

18. Zhao J, Xie LD, Song CJ, Mao XX, Yu HR, Yu QX, Ren LQ, Shi Y, Xie YQ, Li Y, et al: Urantide improves atherosclerosis by controlling C-reactive protein, monocyte chemotactic protein-1 and transforming growth factor- $\beta$ expression in rats. Exp Ther Med 7: 1647-1652, 2014

19. Liu LM, Liang DY, Ye CG, Tu WJ and Zhu T: The UII/UT system mediates upregulation of proinflammatory cytokines through p38 MAPK and NF- $\kappa$ B pathways in LPS-stimulated Kupffer cells. PLoS One 10: e0121383, 2015

20. National Research Council. Guide for the Care and Use of Laboratory Animals. 8th Edition. The National Academies Press, 2011. doi: 10.17226/12910.

21. Sarhadynejad Z, Sharififar F, Pardakhty A, Nematollahi MH, Sattaie-Mokhtari S and Mandegary A: Pharmacological safety evaluation of a traditional herbal medicine 'Zereshk-e-Saghir' and assessment of its hepatoprotective effects on carbon tetrachloride induced hepatic damage in rats. J Ethnopharmacol 190: 387-395, 2016.

22. Yan J, Jie Z, Hou L, Wanderley JL, Soong L, Gupta S, Qiu S, Chan T and Sun J: Parenchymal expression of CD40 exacerbates adenovirus-induced hepatitis in mice. Hepatology 53: 1455-1467, 2011.

23. Li X, Li X, Luo R, Wang W, Wang T and Tang H: Detection of KIT genotype in pigs by TaqMan MGB Real-time quantitative polymerase chain reaction. DNA Cell Biol 37: 457-464, 2018.

24. Li YY, Ge QX, Cao J, Zhou YJ, Du YL, Shen B, Wan YJ and Nie YQ: Association of Fusobacterium nucleatum infection with colorectal cancer in Chinese patients. World J Gastroenterol 22: 3227-3233, 2016.

25. Lu Y, Lin Y, Huang X, Wu S, Wei J and Yang C: Oxaliplatin aggravates hepatic oxidative stress, inflammation and fibrosis in a non-alcoholic fatty liver disease mouse model. Int J Mol Med 43: 2398-2408, 2019.

26. Urtasun R, Lopategi A, George J, Leung TM, Lu Y, Wang X, Ge X, Fiel MI and Nieto N: Osteopontin, an oxidant stress sensitive cytokine, up-regulates collagen-I via integrin $\alpha(\mathrm{V}) \beta(3)$ engagement and $\mathrm{PI} 3 \mathrm{~K} / \mathrm{pAkt} / \mathrm{NF} \mathrm{B}$ signaling. Hepatology 55: 594-608, 2012 .

27. Srungaram P, Rule JA, Yuan HJ, Reimold A, Dahl B, Sanders C and Lee WM; Acute Liver Failure Study Group: Plasma osteopontin in acute liver failure. Cytokine 73: 270-276, 2015.

28. Zhou M, Wang H, Zeng X, Yin P, Zhu J, Chen W, Li X, Wang L, Wang L, Liu Y, et al: Mortality, morbidity, and risk factors in China and its provinces, 1990-2017: A systematic analysis for the Global Burden of Disease Study 2017. Lancet 394: 1145-1158, 2019.

29. Wang W, Jiang L, Ren Y, Shen M and Xie J: Characterizations and hepatoprotective effect of polysaccharides from Mesona blumes against tetrachloride-induced acute liver injury in mice. Int J Biol Macromol 124: 788-795, 2019.

30. Munakarmi S, Chand L, Shin HB, Jang KY and Jeong YJ: Indole-3-carbinol derivative DIM mitigates carbon tetrachloride-induced acute liver injury in mice by inhibiting inflammatory response, apoptosis and regulating oxidative stress. Int J Mol Sci 21: 2048, 2020.

31. Zhang W, Dong Z, Chang X, Zhang C, Rong G, Gao X, Zeng Z, Wang C, Chen Y, Rong Y, et al: Protective effect of the total flavonoids from Apocynum venetum $\mathrm{L}$. on carbon tetrachloride-induced hepatotoxicity in vitro and in vivo. J Physiol Biochem 74: 301-312, 2018.

32. Zira A, Kostidis S, Theocharis S, Sigala F, Engelsen SB Andreadou I and Mikros E: 1H NMR-based metabonomics approach in a rat model of acute liver injury and regeneration induced by $\mathrm{CCl}_{4}$ administration. Toxicology 303: 115-124, 2013. 
33. Kuang Y, Han X, Xu M, Wang Y, Zhao Y and Yang Q: Oxaloacetate ameliorates chemical liver injury via oxidative stress reduction and enhancement of bioenergetic fluxes. Int $\mathbf{J}$ Mol Sci 19: 1626, 2018.

34. Liu Y, Wen PH, Zhang XX, Dai Y and He Q: Breviscapine ameliorates $\mathrm{CCl}_{4}$-induced liver injury in mice through inhibiting inflammatory apoptotic response and ROS generation. Int $\mathbf{J} \mathrm{Mol}$ Med 42: 755-768, 2018

35. Wang M, Niu J, Ou L, Deng B, Wang Y and Li S: Zerumbone protects against carbon tetrachloride $\left(\mathrm{CCl}_{4}\right)$-induced acute liver injury in mice via inhibiting oxidative stress and the inflammatory response: Involving the $\mathrm{TLR}_{4} / \mathrm{NF}-\mathrm{\kappa B} / \mathrm{COX}-_{2}$ pathway. Molecules 24: 1964, 2019.

36. Wu T, Shen M, Liu S, Yu Q, Chen Y and Xie J: Ameliorative effect of Cyclocarya paliurus polysaccharides against carbon tetrachloride induced oxidative stress in liver and kidney of mice. Food Chem Toxicol 135: 111014, 2020.
37. Liang DY, Liu LM, Ye CG, Zhao L, Yu FP, Gao DY, Wang YY, Yang ZW and Wang YY: Inhibition of UII/UTR system relieves acute inflammation of liver through preventing activation of NF- $\kappa$ B pathway in ALF mice. PLoS One 8: e64895, 2013.

38. Lu Y, Hu D, Ma S, Zhao X, Wang S, Wei G, Wang X, Wen A and Wang J: Protective effect of wedelolactone against $\mathrm{CCl}_{4}$-induced acute liver injury in mice. Int Immunopharmacol 34: 44-52, 2016.

39. Mo W, Wang C, Li J, Chen K, Xia Y, Li S, Xu L, Lu X, Wang W and Guo C: Fucosterol protects against concanavalin A-induced acute liver injury: Focus on P38 MAPK/NF- $\kappa$ B pathway activity. Gastroenterol Res Pract 2018: 2824139, 2018.

(i) (9) This work is licensed under a Creative Commons Attribution-NonCommercial-NoDerivatives 4.0 International (CC BY-NC-ND 4.0) License. 